\title{
Building Back Better? Peace Education in Post-Conflict Africa
}

\author{
Clive Harber
}

This article analyzes the role of schools in helping to build peace in post-conflict countries in Africa. It argues that schools cannot be built back the same after a violent conflict because they have often been complicit in the violence in the first place. Thus the need to "build back better." There is much belief in the potential of schools to contribute to peace in post-conflict societies. However, evidence on the role of schools in terms of the introduction of courses in peace education and attempts to change the structures, relationships, and practices of schools in a more peaceful direction is not particularly encouraging. Many significant obstacles remain to schools successfully contributing to peace.

Keywords post-conflict, Africa, schools, peace, violence

\section{Introduction}

This article concerns the role of peace education in "building back better" in postconflict states in sub-Saharan Africa. The phrase "building back better" is used in discussions of education in post-conflict contexts because building schools back as they were-a return to "normality" - might simply help to continue and prolong problems of violence in the society concerned. This is because in many conflict affected states schools have been violent institutions and have played a role in reproducing and perpetrating violence in the first place (Bush and Salterelli 2000; Davies 2004; Harber 2004; Pinheiro 2006). Thus, there is a need to not only build schools back physically and organizationally but to "build back better" and build back different from the existing, dominant model of schooling so that schools are able to make a positive contribution towards building peace rather than contributing towards violence.

This existing and dominant model of schooling is an essentially authoritarian one and one that was inherited by African countries during colonialism and perpetuated subsequently by post-colonial governments (Harber 2004, Chapters 
2 and 4). Hawkins (2007), for example, argues that this traditional, nondemocratic/authoritarian model of schooling persists, is dominant globally, and is taken for granted. In discussing what he terms "The Intractable Dominant Educational Paradigm," he argues that the features of this dominant paradigm, which exists almost everywhere despite the political nature of the regime, are that:

- An authoritarian relationship often lies at the core of the teacher-learner interaction;

- Teachers generally discourage discussion and questioning, and adhere to textbooks;

- A principal function of schooling is to select entrants to the next educational level;

- The selection is through a highly competitive examination system which requires the reproduction of rote learning rather than critical thought;

- The main activities of the formal school system are directed towards preparing pupils for these examinations; and

- Students and parents are preoccupied with certificate-status rather than with the essence of what is taught (ibid., 150-151).

The problem, according to Hawkins, is that this model of schooling has come, almost universally, to be regarded as the only possibility, the only model of a "real" or "normal" school.

Thus, "building back better" involves a process of considerable education change in terms of building respect, justice, and inclusiveness and addressing and solving the root causes of violent conflict. The process also includes both relational transformation and structural transformation (Gill and Niens 2014b, 11-12). Novelli and Smith $(2011,7)$ put it that:

Peacebuilding is essentially about supporting the transformative processes any postconflict society needs to go through, and these changes unfold over generations. Developments through the education sector represent a very important part of this transformative process, with huge potential to impact positively or negatively on underlying conflict triggers in the medium to long term.

The United Nations Educational, Scientific and Cultural Organization (UNESCO) $(2011,138)$, however, notes the difficulty of defining a conflict and thus a post-conflict society, calling it an "inexact science." Nevertheless, they argue that "armed conflict" has to entail "contested incompatibility" over government and/or territory where the use of armed force is involved, and where one of the parties to the conflict is the state. This definition is an attempt to differentiate between organized, politically motivated violence and generalized violence linked to criminal activity. They put forward a list of thirty-five countries affected by armed conflict between 1999 and 2008 of which thirty were low income countries. Of these thirty-five countries, ten were considered postconflict in that they had been at peace for less than ten years but could still be 
considered as being at risk of a relapse back into violence. Indeed, according to Quaynor $(2011,34)$, political scientists working with databases that analyze conflict categorize an ongoing conflict as one which results in more than twentyfive deaths per year. However, Davies $(2016,182)$ questions whether a state can be seen as post-conflict, given that, while there may be a cessation of violence, the roots of the conflict may not have been addressed.

Many African countries have experienced violent conflict. The Institute of Economics and Peace constructs the "global peace index" (www.visionofhumanity. org). This measures violence across societies according to a diverse range of indicators-for example, ease of access to small arms and light weapons, level of organized conflict, level of perceived criminality in society, level of violent crime, likelihood of violent demonstrations, military expenditure as a proportion of gross domestic product, number of deaths from organized conflict, number of homicides per 100,000 people, political instability, number of security officer and police per 100,000 people, and relationships with neighbouring countries. In 2015, of the 162 countries, twelve sub-Saharan African states appear in the top of half of more peaceful countries with Botswana the highest and most peaceful at thirty-six and Togo at 80. The other twenty-nine sub-Saharan African countries were ranked in the bottom half.

Such violence in the wider society both affects schools and is affected by schools. This article discusses education for peace in sub-Saharan Africa, but is particularly concerned with evidence on attempts at peace education in postconflict countries sub-Saharan Africa. As will be further discussed below, much has been claimed about the potential of peace education to contribute to peace building, but how much does the evidence support these claims?

\section{The Peace Potential of Education}

The belief that education has the potential to contribute to peace building is a key part of the literature on education in post-conflict societies. For example, it has been at the forefront of UNESCO thinking for some time: "Since wars begin in the minds of men, it is in the minds of men that the defences of peace must be constructed" (UNESCO 1945, first sentence). UNESCO has repeated this faith in education as contributing to peace in a number of its annual education global monitoring reports: "No country can hope to live in peace and prosperity unless it builds mutual trust between its citizens, starting in the classroom...Schools should be seen first and foremost as places for imparting the most vital of skills: tolerance, mutual respect, and the ability to live peacefully with others" (UNESCO 2011, 3). "If global development goals are to be achieved, it is vital that to reduce conflict, which has held back progress towards the Millennium Development Goals-and education is a key way of doing so" (UNESCO 2013/2014, 175). 
There is also considerable optimism about the potential role of education in contributing to peace in the academic literature. King $(2011,148)$, for example, notes that, beyond restoring normality and helping to hope and cope, schooling can make a contribution to peacebuilding and conflict prevention. Shepler $(2011,200)$ adds that "teachers have important roles to play in the structural transformation of societies, particularly in post-conflict contexts." Brock (2011, 27) argues that post-conflict contexts "present an opportunity to adopt a fundamentally new approach to education," and Ezati et al. $(2011,185)$ note that "literature on post-conflict reconstruction highlights the role of education in peacebuilding. It illustrates the importance of schools as sources of intervention and as instruments to overcome violence and improve respect for humanity."

Sharkey $(2008,569)$ adds that "it is broadly assumed that following armed conflict, education is a crucial means to support the transformation of society from war-torn to reconstructed," and a literature review for the British Department for International Development talks of "the potential of education to achieve peacebuilding objectives and contribute to social transformation in post-conflict settings" (Novelli et al. 2014, 4). An edition of a journal devoted to the role of education in post-conflict peacebuilding (Compare: A Journal of Comparative and International Education Volume 44 Number 1) begins with this statement: "In the context of post-conflict and divided societies working towards peace, it has been widely recognised that education can play a critical part in either fermenting community division or in assisting socio-political change leading to the reconstruction of community relationships" (Gill and Niens 2014a, 1).

However, as pointed out in the introduction to this article, if this potential is to be realized then education will need to be changed. Indeed, perhaps the keyword here is transformed as the role of transformed schooling in contributing to peacebuilding is a key theme of the education and post-conflict society literature. As Williams $(2006,17)$ put it in a Commonwealth handbook which gives advice on education and post-conflict reconstruction:

If education is to play a positive role in conflict avoidance and prevention it must do far more than include subject matter in the school curriculum under the rubric of 'peace' or 'tolerance,' as a set of precepts for children and adults to learn and follow. The very structure of education, and the way the system is organised and resources are allocated, must be built on principles of equal rights for all sections of the population and respect for its different traditions and cultures.

Yet there are serious practical and logistical problems about building back at all in post-conflict societies, let alone building back better. Buckland, for example, writing in his capacity as a Senior Education Specialist at the World Bank, sets out some of the problems facing education in many post conflict states as: 
- An inability of recovering states to fund either capital or recurrent expenditure as few states have access to domestic revenue sufficient to keep systems running

- Chronic shortages of qualified teachers - any have been killed or fled, and many of those who remain or return are snapped up by international agencies and NGOs

- Oversupply of under-qualified or unqualified teachers

- The sheer number of war-affected youth, demobilised soldiers and young people who have not completed basic education

- Poor record keeping, corruption and lack of transparency in education governance: salaries are often paid to 'ghost' teachers

- The 'relief bubble' in international financial support often subsides before a more predictable flow of reconstruction resources can be mobilised: relief agencies often scale back operations before development-focused agencies can be mobilised (Buckland 2006, 7)

Smith (2010, 18-19) adds in relation to the desired role of teachers in "building back better" via the promotion of reconciliation:

Ensuring that teachers have the capacity to undertake reconciliation education is an enormous challenge. The conflict reduced the pool of teachers, making it even harder to find those with the skills to teach a sensitive new topic. Teachers themselves are part of the culture and have their own values. The emotional issues surrounding the past conflict make enormous demands on the traditionally technical background of teachers. Addressing conflict and reconciliation, of course, requires knowledge of child rights, expertise in pedagogy and skills in facilitating discussion of controversial issues. Teachers are probably the single most important factor in mediating the curriculum and the values it conveys, and any education strategy needs to take account of their central role.

Nevertheless, one key aspect of any desired transformation of education is the introduction of a new subject or theme into the curriculum consciously aimed at creating more peaceful individuals and societies-peace education. The nature of peace education has been much discussed, so here we will simply note that Bajaj offers the following seven core competencies for peace education:

1. Critical thinking and analysis

2. Empathy and solidarity

3. Individual and collective agency

4. Participatory and democratic engagement

5. Innovative education and communication strategies

6. Conflict resolution skills

7. Ongoing reflective practice (Bajaj 2016, 109).

Thus the aim of peace education is to teach the knowledge, skills, values, and behaviors that contribute to peace. As a result, people will be in a position to solve problems and disagreements in and between communities in a peaceful manner. 
Cunningham $(2015,25-26)$ argues that successful peace education requires the development of "emotional intelligence" which involves self-awareness and selfcontrol as well as inter-personal factors such as sympathy for others, sensitivity, and cooperation skills. However, in an area of conflict or post-conflict, peace education is about changing the mind-set concerning the collective other, understanding each other's narrative and one's own group's responsibility for others suffering.

However, as Bajaj and Hantzopoulos $(2016,3)$ argue, although in one sense peace education may be a curriculum subject, in order to succeed it needs a wider transformation of content, pedagogy, structures, educational practices, relationships between educators and learners, and the systems by which we measure the outcomes of education. This is because in order to achieve a successful outcome for peace education where the majority of people (and therefore societies) who operate in this way (i.e. who can critically analyze, can exercise empathy, can exercise participatory agency in a democratic manner, etc., as above), then peace education needs to be about more than just a timetabled school subject. Peace education in the curriculum in some form may be necessary but not sufficient. The rest of schooling must be congruent with the above competencies-the way schools are managed, the ways teachers and pupils behave, disciplinary codes, content, and teaching methods across the curriculum must reflect these competencies and behaviors and the democratic, inclusive, and participatory values behind them.

Yet there are a number of recognized problems with, and obstacles to, peace education internationally. One is that peace education is unlikely to work where a conflict is ongoing or erupts periodically. Thus, in the context of on-going violent conflict such as Israel-Palestine, reconciliation through formal education could be near to impossible. Talking of a Palestinian young person undergoing occupation, Hart $(2011,19)$ writes, "it is doubtful that her feelings would be assuaged by finesounding messages delivered in the classroom, no matter how expertly designed and delivered, when her daily experiences of occupation remain unchanged."

Allied to this is the problem that the political context for educational transformation and peace education can rapidly change. Potentially positive work by educationalists can be negated by a return of violence or a change of political control. In volatile contexts, sustainability of an innovation is an issue. Novelli et al. $(2014,59)$ further note that peace education in conflict affected states is not always welcome and that "the language of peace is not necessarily welcome everywhere"- "peace education" or "education for peace" is not always favored by governments that wish to attribute blame for conflict on particular (historical) groups, or that see themselves in a post-conflict situation where peace education is not necessary.

A further issue is that, even when it does appear, the principles of peace education are incompatible with the dominant ethos and structures of schooling. 
Essentially, the authoritarian, assessment-driven, and competitive environment of most schooling is not one where peace education can thrive and prosper (Harber and Sakade 2009). Thus, Gill and Niens (2014b, 14), for example, note that mass formal schooling might not be seen by some as the best vehicle for this because of incompatibilities between it and the values and practices necessary for peacebuilding. This is particularly true where corporal punishment is still widely used (Harber 2014, 107-110).

Another problem with peace education is that many students reject critical pedagogy because of the pervasive, taken-for-granted, and dominant teachercentred pedagogies in schools (Zembylas 2016, 24). Moreover, many teachers lack the training and, thus, skills and disposition to teach the necessary controversial issues in the classroom (Harber and Mncube 2012, 92-94). Moreover, the experience of teacher education in Africa may well not have prepared teachers to work in a democratic way in classrooms (Harber 2017, Chapter 5). It is also quite difficult to assess the impact and outcomes of peace education which are essentially more about skills, values, and behaviors than knowledge retention. Especially as these are often long term goals (Harber and Sakade 2009).

\section{Peace Education in Sub-Saharan Africa: Some Evidence}

While there is increasing evidence concerning the role of schools in post-conflict African societies, the following review has had to exercise some selection due to issues of word length. However, the flowing discussion includes a variety of countries from East, West, and southern Africa where sufficient evidence exists. The findings for Africa discussed here also consistently reflect the trend of findings for other African countries (and other non-African countries) in a wider study the author is currently carrying out on the role of schooling in post-conflict developing societies globally.

Barakat et al. $(2013,134)$ describe the development of a peace education curriculum by the Ministry of Education and United Nations International Children's Fund (UNICEF) in Kenya after the post-election violence of 20072008. The aim was to build the resilience of local communities and schools most affected by post-election violence by training teachers to teach conflict-resolution skills. They note that "following its perceived success" it was rolled out across the country, though limitations on funding necessitated a top-down "cascaded training system for teachers." However, no systematic monitoring and evaluation took place of this or other peace initiatives, so "it was hard to reliably measure the impact beyond the perceptions of those interviewed" (ibid.). Mendenhall and Chopra (2016) add that the objectives of the program were to promote peaceful coexistence among learners, hence contributing to peace and national cohesion. The objectives of the peace education program entailed creating awareness among 
learners about the causes of conflict and developing the conflict resolution skills mentioned above. It also aimed to help students become good citizens in their local communities, countries, and the wider world by respecting cultural diversity and ensuring social justice. However, they note a series of challenges that have emerged since the program was initiated six years previously (ibid., 96-99).

First, despite an intention to mainstream peace education across all subjects, this has not happened: "At best, peace education is taught through the life skills course, which is offered in a lesson of approximately thirty minutes, once per week...Since life skills is not an examinable subject, it is common for teachers not to teach the weekly course at all" (ibid., 96). Second, despite efforts to reach teachers through various training mechanisms, there is still a lack of capacity among teachers to implement peace education and a difficulty in accessing relevant materials. Third, it has been difficult to secure ongoing support for peace education when it has proven difficult to measure the effectiveness and outcomes of the program. Further, problems included the difficulty of moving away from ingrained teacher-centred methods in the classroom, a lack of peace education training in Kenyan universities, the need for more time and resources in a program that aims to develop skills and change behavior and the need for a more social science approach to teaching about the causes of violence and inequalities that also includes teaching about controversial issues (ibid., 104-105).

Another recent study by Lauritzen (2016) reports on research in one case study which focuses on a primary school in Nakuru that had been directly affected by violence and has introduced a peace education program as a result. Lauritzen notes that the Kenyan Peace Education Programme is based on the idea of education as transformation, but, importantly for the present article, also notes that the Peace Education Programme was not widely implemented in Kenya in the way that policy-makers had planned. Thus, Kenya does not provide evidence of system-wide "build back better" in a more peaceful and democratic direction, but the evidence from the case study does provide some useful and informative insights. The overarching themes of the Peace Education Programme were patriotism, similarities and differences, inclusion and exclusion, listening, better communication, handling emotions, perceptions and empathy, cooperation, assertiveness, problem solving, negotiation, mediation, and conflict-resolution. In this particular school, peace education was implemented as part of Life Skills, a no-exam subject taught once a week for pupils in grades one through eight. This immediately raises the issue of the status of the subject in the eyes of pupils, teachers, and parents-assessment and grading can be a powerful signifier of the extent to which a subject is taken seriously.

The case study school in Kenya aimed at "building back better" following the conflict and had declared themselves a school of best practices in peace education, which they saw as building peace within individuals, interpersonal relationships, and the community at large. Observation in the school showed 
that peace slogans were exhibited, that the school encouraged a sense of sharing, discouraged tribalism, and stressed talking to each other as a form of mediation of conflict. However, pupil diaries suggested that corporal punishment was still practiced in the school. One diary stated, "today I witnessed two girls being caned. The girl was caned for not finishing the teacher's work and the second for being late" (ibid., 80). The head teacher said that on some occasions the teachers and herself used corporal punishment, and while they were moving toward banning such practices, this was happening slowly. As the author notes, such practices "stand in stark contrast to the notion of non-violence" (ibid.). Moreover, observation of teaching suggested that teachers were reluctant to teach about the nature and causes of the violence in their community that had brought about the need for a peace education program in the first place, offering instead a "sanitized" version of the curriculum. This reluctance to teach about controversial issues in the classroom is part of wider global pattern (Harber and Mncube 2012, 9294). Thus, while the school in Kenya had made some changes, the distribution of power and authority in the school and classrooms had stayed much the same and the messages of peace were flatly contradicted by the continuing use of corporal punishment.

Indeed, another study of an explicit peace education program in primary schools and primary teacher colleges was conducted in Northern Ugandathe Revitalising Education, Participation and Learning in Conflict Areas Peace Education Programme (REPLICA-PEP) (Najjuma 2011). This was a comprehensive package of six integrated programs which included peace education, leadership and governance, psychosocial care/guidance and counselling, performing arts and learning in schools, community integration, and promotion of girl child education and mentoring. Overall, REPLICA-PEP aimed to make schools peaceful, safe, and enjoyable learning places for learners by promoting a participatory, child-centred approach to the teaching of peace education (ibid., 169). The study focused on the peace education element which aimed at producing young people who understand the causes and effects of conflicts and have skills to prevent and resolve conflicts using non-violent means. Indeed, one key aim of the peace education programs was to "eliminate violence and bullying in schools." However, although teachers in the study were aware of the aims and objectives of the peace education project, "absent from teachers' views is the objective of peace education to eliminate teacher perpetuated and school system violence" (ibid., 136). Indeed, in the views of Centre Coordinators, REPLICA-PEP officials and teachers seem to believe that the responsibility for change for peace lay with the learners and was less about teacher and school system change (ibid., 139).

As in Kenya, Najjuma found in Uganda that teachers were reluctant to talk about the controversial issues of the historical roots of the Lord's Resistance Army and Government of Uganda conflict, and there was evidence of stigmatisation of 
formerly abducted children in school but no teaching about this topic. Moreover, while teachers claimed to be using learner-centred methods in interviews and in lesson plans, her observations of classroom practice were that they were more teacher-centred "as lessons were dominated by teacher initiated activities to direct and control the class and less of learner interaction, group activities, dialogue, and participation" (ibid., 220). Observation also showed that the need to cover subject-based content of examinable subjects and examination pressures led to both teacher-centred learning and the content of peace education being inadequately covered due to lack of time and commitment by teachers. The study found that the program had only had a limited impact, more in cognitive terms than in terms of skills or attitudes. The program did lead to more pupil awareness and general knowledge about peace issues, but there was less competence in the application of conflict resolution skills such as negotiation, dialogue, reconciliation, conflict prevention strategies, problem solving, and anger management. "This is not surprising as pupils were hardly given an opportunity to practice the personal, social and conflict resolution skills in structured settings like classrooms or real situations in the playground or outside the school" (ibid., 297).

Moreover pupils' views and attitudes did not show evidence of empathetic attitudes towards returnees from the conflict, those that had been abducted, victims of bullying at school, or victims of war or any form of violence. As Najjuma points out, it is easier to add new educational initiatives than to change old practices because a change in educational practice is a fundamental political threat as it challenges structures of authority, dominance, and control. Thus, continuing teacher-centred teaching and learning strategies and the asymmetrical relationships of conventional schooling in a post-conflict context may well have limited the development of peaceful behavioural outcomes. Indeed, she adds that, while REPLICA-PEP and Ministry of Education officials were of the view that the peace education program could be sustained through existing school structures, this was a challenge as the school structures are authoritarian and perpetuate symbolic violence through a pedagogy that exists within the context of very unequal power relationships between staff and pupils (ibid., 299, 300, 302). The potential success of the peace education program was also not helped, as in Kenya above, by the continuing use of corporal punishment by teachers (the majority) who were not trained in peace education. Indeed, while teachers cited improved relationships between them and the pupils as a result of the peace education program, the pupils in the study still cited negative comments and responses from teachers, abusive and belittling language used by some teachers and pupils, being caned by teachers, theft, fighting at school, provocation to fight by peers (especially boys), and discrimination in punishment (especially for returnees and over age pupils) (ibid., 275, 293).

Not helping the possibility of educational transformation in practice were a 
series of post-conflict contextual factors: a continuing belligerent environment that reinforced forms of violence, poverty, lack of school meals, dropout and truancy, early marriages, large class sizes, teacher attrition to peaceful areas, less teacher commitment, creativity and professionalism, shortages of instructional materials, and lack of school records (ibid., 305).

Overall, she concluded that "the findings of this study suggest that conventional schooling encourages circular alignment to tested subjects, teachercentred methods of teaching that enhance cognitive knowledge acquisition, and less interactive and inclusive modes of assessment" (ibid., 315). Cunningham $(2015,81,113)$ adds, in relation to his study of northern Uganda, that there were peace clubs in schools but club membership is voluntary and does not cover all pupils, and many clubs existed more in theory than in practice.

In Sierra Leone, Bretherton et al. (2005) describe a peace education kit to be used in conjunction with a child-centred pedagogy. Unfortunately, no real evidence is provided about whether this worked or not and it was impossible to find any other research on the project. Baxter (2013) further describes an INEE (Inter-Agency Network for Education in Emergencies) peace education initiative in Sierra Leone known as the Emerging Issues Programme. The course was designed as a three year course for teachers in training and adapted for distance and intensive six week in-service courses. However, Baxter (ibid., 157-158) is unclear as to the success or impact of the courses:

The programme was less activity-based than the INEE Peace Education Programme but incorporates the participatory pedagogy so necessary. Unfortunately this is extraordinarily difficult to teach through a distance education course and likewise within the confines of a forty-five minute lecture. The intensive six-week course was apparently very successful but I have no word on the efficacy of the other two approaches.

However, these programs seem unlikely to have been particularly successful given the contextual factors described by Novelli and Higgins (2017) who discuss evidence of the low motivation and morale and poor conditions of teachers in Sierra Leone. One study noted that teaching in Sierra Leone is an unattractive and unappreciated profession with teachers contending with low pay, late pay, or no pay at all. The "constraints on teachers' personal and professional agency" and "professional disempowerment" (ibid., 39), which are the result of these conditions, are unlikely to make many teachers wish to engage in personal, professional, and pedagogical transformation. Indeed, Novelli and Higgins note that these working conditions have undermined any peacebuilding capacity the teachers might have (ibid., 40). Moreover, any contribution to peacebuilding by schools in Sierra Leone would need to work on eliminating gender inequities and gender violence, but educational policy making at both the international 
and national level has emphasised the expansion of girls' access to schooling and quantitative targets rather than what goes on in schools which does little to attempt to transform unequal gender relations. The authors quote from a study which argues that, as a result, curricular reforms to integrate domestic violence and discrimination against women as well as the promotion of gender equity through classroom teaching have been neglected and this has led to "the failure of such interventions to inform and equip boys and girls, through education, to challenge deep-rooted patriarchal cultural attitudes and practices" (ibid., 38). Schooling in Sierra Leone is further discussed in the next section.

\section{Structures, Practices, and Relationships}

It was argued above that educating for peace involves more than just a timetable subject. So, what is the evidence that schools in post-conflict countries in subSaharan Africa have changed their structures, practices, and relationships in a peaceful direction?

Cunningham's (2015) study of schools in northern Uganda found that, though there were occasional positive examples of peaceful practices such as some pupils being involved in making class rules and teachers adjudicating in disputes in a fair and reasonable ways, overall the schools seemed to be making only a very minor contribution and negative aspects remained. For example, school prefects tended to enforce the school rules and the emphasis of their role was on a hierarchical system of top-down authority. Furthermore, corporal punishment was still sometimes used despite officially being banned (ibid., 84, 118).

Matsumoto's (2011) study of post-conflict Sierra Leone points out that good students-those with a "blessing"-are perceived to be those that obey teachers, the principal, and others. Yet, Wright (1997) is very critical of the pre-war education system in Sierra Leone for having an over-emphasis on conformity and sycophancy, which has helped to facilitate a population that is too docile in the face of dictatorial leaders, even noting that the very violent Revolutionary Front had "an unusually high proportion of ex-teachers and ex-students in its ranks" (ibid., 25). Sharkey's (2008) study of an all-girls school in post-conflict Sierra Leone examined whether it functioned as a safety zone for girls. Certainly, the girls faced danger and fear of sexual harassment on the way to and from school but:

The broad discourse of the benefits of education as a means to rehabilitate and support recovery following war was also contradicted at this school by the continuing high levels of in-school violence against girls. Here the Principal, together with the teachers, created an atmosphere where an ethos of violence, humiliation and berating 
of students was normalised, thereby sanctioning and permitting violence to occur (ibid., 573).

This was despite an overt discourse from the teachers of the need for care and kindness and the aim of developing self-confidence and self-esteem in the girls. However, despite a rhetoric of concern, teachers rarely smiled at students or had friendly conversations with them. Interestingly, the principal condoned the many absences of teachers from the school but demanded strict obedience and conformity to the rules by students. Sharkey summarizes the situation as follows:

The discourse of the benefits of girls' education in post-conflict situations is juxtaposed with girls' experiences of crowded conditions, inadequate resources, the often irrelevant subject matter, authoritarian classrooms, and pervasive violence and fear in school-all part of the landscape of girls' schooling experiences. In spite of a discourse of girls' empowerment, students had no adults to turn to concerning in-school violence, yet they remained grateful for receiving an education. In the Brookfields School, classrooms were cramped with small tables shared by up to four girls who sit on narrow benches. There was no electricity, few pedagogical resources, and often only the teacher had a textbook. Teaching was rote-based and the amount of formal learning that took place at the school was limited. An atmosphere of fear and anxiety existed among the students within the classrooms. Teachers used physical violence against the students for reasons ranging from providing an incorrect answer to a teacher's question, whispering in the classroom, arriving to school late, to incidences when a teacher believed a girl thought too highly of herself, or felt that the class was learning too slowly. In this latter case, the whole class could be caned. Students can be beaten on the head, face, back, buttocks, chest, arms, and legs. In other situations, groups of girls or an individual girl were made to kneel on the concrete floor. Physical violence by teachers on students was commonplace and could be harsh, and most students had scars left from canings at school. In response to this, one student stated, 'It hurts so much you can even feel it in your heart. Even your heart hurts.' Teachers also regularly berated, insulted, and demeaned students for reasons such as not being smart enough, not speaking loudly enough when answering a question, being too beautiful, or not being beautiful enough. One teacher commented to a student, 'You're not important. No one would even want to look at you.' Another teacher, after calling over a colleague to look at a student's well-worn uniform, said to the student, 'Your uniform is the worst in the school. You should be ashamed of its condition.' Later, the teacher explained that that student's family lived in such poverty that the girl often went for two days without eating. Other comments, such as that a student was stupid or that the teacher did not like her, were not uncommon (ibid., 574).

In the face of her evidence, Sharkey refers to the "myth" of education as empowering as students desired education and learning but in a situation where very few would ever achieve the satisfying employment, economic prosperity 
which they sought (ibid., 575).

Kearney (2011) examined the Ingando Peace and Solidarity Camp in Rwanda which exists to strengthen Rwandan identity as opposed to ethnic ties. The argument is that the top-down, authoritarian, and unequivocal approach of the camp is more a method of establishing unity and social cohesion through a single view of history rather than an attempt at reconciliation through discussion and open debate. Moreover, this authoritarian style is reinforced by intense military training involving physical punishment.

One of the most widely researched countries in Africa in terms of postconflict reform is perhaps South Africa. Though South Africa did not experience the all-out civil war and fighting experienced by other countries in Africa, the anti-apartheid struggle and resistance to it was marked by sporadic but increasing violence from 1948 to the early 1990s. Indeed, as Christie (2016, 434-435) points out in relation to South Africa, "it is worth remembering that the liberation struggle against apartheid was violent and protracted, intensifying towards its end. Some of the most violent struggles occurred in the 1980s, with over 10,000 people killed in acts of violence and reprisals in KwaZulu-Natal and on the Witwatersrand between 1985 and 1993." She adds that, throughout the 1980s, the South African government used harsh and violent measures in response to political protest. Political activists were assaulted, detained, tortured, incarcerated, and many were murdered, and in 1986 the South African government declared a state of emergency over the entire country that lasted until 1990.

Mthiyane (2013) argues in relation to South Africa that a general feature of post-conflict societies is the pervasive antagonism, mistrust, and lack of faith among former political adversaries and that, in his view, South Africa "still has many features of a fragmented society such as lack of social cohesion and mistrust among various race groups, even though as a country we like to embrace the notion of a rainbow nation, violence, racism, pervasive antagonism and many other features of a post-traumatic nature" (ibid., 19).

Post-apartheid educational reform contains a clear commitment to introducing more democratic and less violent forms of schooling. Thus, the Constitution of the Republic of South Africa (RSA) aims at ensuring democracy and, as such, is permeated by democratic principles. For example, the Constitution of RSA (1996) in its preamble emphasizes a new set of values in moving away from the past so as to "heal the divisions of the past and establish a society based on democratic values, social justice and fundamental human rights; lay the foundations for a democratic and open society...improve the quality of life of all citizens and free the potential of each person; and build a united and a democratic South Africa" (Republic of South Africa 1996a, 1).

As a result, post-apartheid education policy has had an overwhelming emphasis on the role of education in helping to create a more democratic and peaceful society: 
The realization of democracy, liberty, equality, justice and peace are necessarily conditions for the full pursuit and enjoyment of lifelong learning. It should be a goal of education and training policy to enable a democratic, free, equal, just and peaceful society to take root and prosper in our land, on the basis that all South Africans without exception share the same inalienable rights, equal citizenship and common destiny, and that all forms of bias (especially racial, ethnic and gender) are dehumanising (Department of Education 1995, 22).

There is some evidence to suggest that democratic change has taken place in some South African schools. For example, a study of three such schools notes their "willingness to embrace change and in their commitment to implementing a new educational ideology aimed at fostering a non-violent, non-racist democratic society" (Harber and Muthukrishna 2000, 430).

As part of the reform of schools in a democratic direction in South Africa, all secondary schools should have a functioning school governing body on which is members of the Representative Council of Learners, an elected student body. The idea behind this was to foster democratic school governance, thereby introducing a school governance structure that involves all educational stakeholder groups in active and responsible roles in order to promote issues of democracy: tolerance, rational discussion, and collective decision-making (Department of Education 1996, 16). Naidoo (2012) studied two functioning democratic schools in the Durban area. She found that the principals of these schools displayed strikingly similar characteristics, including commitment, openness, integrity, excellent communication and interpersonal skills, being good listeners, and having faith in others. The way the principals practiced democracy in the two schools had many similarities:

These principals practiced the sharing of ideas and sharing of expertise. They fostered a democratic culture that embraced the cultures of collegiality, respect, care and trust, listening, participation, communication, consultation and collaboration...At both schools participants made reference to collective decision-making, collaboration and voting as democratic processes. From the responses at both schools the structures that make the school democratic included the staff representatives, staff stewards representing the teacher unions, a fully elected Representative Council of Learners, School Governing Body, Senior Management Team, peer mediators and learning (subject) committees (ibid., 260-261).

However, it is important to stress that a more democratic approach to education in South Africa did not suddenly emerge as policy from nowhere once apartheid, and the struggle against it, ended in 1994. Early experimentation with a democratic forms of schooling began in the African National Congress (ANC) school in exile in Tanzania after 1976 and then gradually emerged as ANC policy, though this was only partially successful and was a warning of the difficulties 
that would face South Africa in trying to implement fundamental change or transformation after 1994 (Harber 1997, 142-145).

Thus, as Christie (2016, 440-441) argues, one of the most sobering lessons of post-conflict reconstruction in South Africa has been that:

The idealism that drove the anti-apartheid struggle and harnessed the energies of a wide spectrum of people hoping for a more just and equitable society was, itself, insufficient to ensure the social reconstruction it aspired to. If anything, the triumph against apartheid fuelled impossible dreams for educational change, and ideals of change did not take into account the kind of work entailed in fundamentally restructuring the education system-or restructuring the political economy. Lack of experience led to unrealistic policies, and political interests of all sorts complicated implementation processes. Drawing on Gramsci's dictum, it could be said that 'optimism of the will' was not accompanied by sufficient 'pessimism of the intellect.' The complexities of change were under-estimated, and as time passed, the new policies themselves brought stresses into the education system, whose poor results could no longer be straightforwardly blamed on apartheid.

Indeed, despite the existence of the democratic principles and practices in schools described above, Naidoo (2012) still found that learners in the two schools she studied were still insufficiently involved in decision-making. In fact, a number of scholars in South Africa have been critical of the actual practices of school governing bodies (see, for example, Naidoo 2005). Studies of the functioning on the new school governing bodies (Bush and Heystek 2003; Ministerial Review Committee 2004; Mncube 2005; Grant Lewis and Naidoo 2006; Brown and Duku 2008) found that members of governing bodies tended to be male, that principals still played a dominant role in meetings and decision-making processes, and that teachers tended to participate in meetings more than other stakeholders. Parents, the numerically dominant group under the legislation, were hampered in many areas by a skills capacity deficit and communication and transportation problems. Learner participation was only moderate and concentrated on fundraising, learner discipline, and sports activities. So, while the structural dimension of democratic governance had been established, power relations, i.e. the dominance of the principal, remained much the same.

It is also important to stress that extreme inequality and the repercussions of apartheid mean that South Africa remains a violent society and that schools are both affected by external violence and continue to both reproduce and perpetrate violence themselves on a consistent and persistent basis. For example, corporal punishment is illegal in South Africa but is still commonly used in school. Sexual harassment and violence against girls by both students and staff is also a regular and widespread phenomenon in South African schools. Bullying, fighting, and racial conflict are not unusual (see Harber and Mncube 2017 for a detailed discussion of violence in South African schools). Thus, it is difficult to see how 
schooling, in general and despite individual exceptions, can be making a major contribution to peace in South Africa.

\section{Conclusion}

Great faith is put in the potential of educational change to help build peace in post-conflict settings globally and this is true for sub-Saharan Africa by building schools back better. However, as the above review of evidence suggests, and despite considerable effort, the reality is that schooling often remains stubbornly difficult to change, let alone transform in a more peaceful direction. Partly this is because shortages of human and physical resources hamper efforts of reconstruction. However, it is also the case that the traditional "intractable paradigm" of authoritarian, hierarchical, and competitive schooling is deeply rooted in the minds and thus practices of education officials, head teachers, teachers, parents, pupils, and school communities. It is seen by many or most as a "given" and is thus impervious to change. Education for peace remains a noble goal for schools in Africa, but the evidence strongly suggests that current practice will need to change more substantially in the future if the goal is to be achieved.

\section{References}

Bajaj, Monisha. 2016. "In the Gaze of Gandhi: Peace education in contemporary India." In Peace Education: International Perspectives, eds. Monisha Bajaj, and Maria Hantzopoulos, 107-124. London: Bloomsbury.

Bajaj, Monisha, and Maria Hantzopoulos. 2016. "Introduction: Theory, research and praxis of peace education.” In Peace Education: International Perspectives, eds. Monisha Bajaj, and Maria Hantzopoulos, 1-16. London: Bloomsbury.

Barakat, Sultan, David Connolly, Frank Hardman, and Vanita Sundaram. 2013. "The role of basic education in post-conflict recovery." Comparative Education 49 (2): 124-142.

Baxter, P. 2013. "Development of the INEE peace education programme." In Learning to Live Together: Education for Conflict Resolution, Responsible Citizenship, Human Rights and Humanitarian Norms, ed. Margaret Sinclair, 148-161. Doha: Protect Education in Insecurity and Conflict.

Bretherton, Diane, Jane Weston, and Vic Zbar. 2005. "School-based peace building in Sierra Leone." Theory Into Practice 44 (4): 355-362.

Brock, Colin. 2011. "Education and conflict: A fundamental relationship." In Education, Conflict and Development, ed. Julia Paulson, 17-32. Oxford: Symposium Books.

Brown, Byron, and Ntombozuko Duku. 2008. "Negotiated identities: Dynamics in parents' participation in school governance in rural Eastern Cape schools and implication for school leadership." South African Journal of Education 28 (3): 431-450.

Buckland, Peter. 2006. "Post-conflict education: Time for a reality check?" Forced Migration Review. http://www.fmreview.org/FMRpdfs/EducationSupplement/03.pdf (accessed 
April 23, 2018).

Bush, Kenneth D., and Diana Saltarelli, eds. 2000. The Two Faces of Education in Ethnic Conflict: Towards a Peacebuilding Education for Children. Florence: UNICEF.

Bush, Tony, and Jan Heystek. 2003. "School governance in the new South Africa." Compare: A Journal of Comparative and International Education 33 (2): 127-138.

Christie, Pam. 2016. "Educational change in post-conflict contexts: reflections on the South African experience 20 years later." Globalisation, Societies and Education 14 (3): 434446.

Cunningham, Jeremy. 2015. Conflict Transformation Through School: A Curriculum for Sustainable Peace. London: IOE Press.

Davies, Lynn. 2016. “The politics of peace education in post-conflict societies." In Building Sustainable Peace: Timing and Sequencing of Post-Conflict Reconstruction and Peacebuilding, eds. Arnim Langer, and Graham K. Brown, 181-199. Oxford: Oxford University Press.

Davies, Lynn. 2004. Education and Conflict: Complexity and Chaos. London: Routledge.

Department of Education. 1995. White Paper on Education and Training. Pretoria: Government Printers.

Department of Education. 1996. South African Schools Bill. Pretoria: Government Printers.

Ezati, Betty Akullu, Cornelius Ssempala, and Peter Ssenkusu. 2011. “Teachers' perceptions of the effects of young people's war experiences on teaching and learning in Northern Uganda." In Education, Conflict and Development, ed. Julia Paulson, 185-208. Oxford: Symposium Books.

Gill, Scherto, and Ulrike Niens. 2014a. "Education as humanisation: a theoretical review on the role of dialogic pedagogy in post-conflict peacebuilding." Compare: A Journal of Comparative and International Education 44 (1): 1-9.

Gill, Scherto, and Ulrike Niens. 2014b. "Education as humanisation: a theoretical review on the role of dialogic pedagogy in peacebuilding education." Compare: A Journal of Comparative and International Education 44 (1): 10-31.

Grant Lewis, Suzanne, and Jordan Naidoo. 2006. "School governance and the pursuit of democratic participation: lessons from South Africa." International Journal of Educational Development 26 (4): 415-427.

Harber, Clive. 1997. Education, Democracy and Political Development in Africa. Brighton: Sussex Academic Press.

Harber, Clive. 2004. Schooling as Violence. London: Routledge Falmer.

Harber, Clive. 2014. Education and International Development: Theory, Practice and Issues. Oxford: Symposium.

Harber, Clive. 2017. Schooling in Sub-Saharan Africa: Policy, Practice and Patterns. London: Palgrave Macmillan.

Harber, Clive, and Nithi Muthukrishna. 2000. "School effectiveness and school improvement in context: The case of South Africa." School Effectiveness and Improvement 11 (4): 421-434.

Harber, Clive, and Noriko Sakade. 2009. "Schooling for violence and peace: How does peace education differ from 'normal' schooling?" Journal of Peace Education 6 (2): 171-187.

Harber, Clive, and Vusi Mncube. 2012. Education, Democracy and Development: Does Education Contribute to Democratisation in Developing Countries? Oxford: 
Symposium.

Hart, Jason. 2011. "Young people and conflict: The implications for education." In Education and Reconciliation: Exploring Conflict and Post-Conflict Situation, ed. Julia Paulson. London: Continuum.

Hawkins, John N. 2007. “The intractable dominant educational paradigm.” In Changing Education: Leadership, Innovation and Development in a Globalizing Asia Pacific, eds. Peter D. Hershock, Mark Mason, and John N. Hawkins, 131-162. Hong Kong: Comparative Education Research Centre.

Kearney, James. 2011. "A unified Rwanda? Ethnicity, history and reconciliation in the Ingando peace and solidarity camp." In Education and Reconciliation: Exploring Conflict and Post-Conflict Situation, ed. Julia Paulson, 151-177. London: Continuum.

King, Elisabeth. 2011. "The multiple relationships between education and conflict: Reflections of Rwandan teachers and students." In Educating Children in Conflict Zones, eds. Karen Mundy, and Sarah Dryden-Peterson, 137-151. New York: Teachers College Press.

Lauritzen, Solvor Mjøberg. 2016. "Building peace through education in a post-conflict environment: A case study exploring perceptions of best practices." International Journal of Educational Development 51: 77-83.

Matsumoto, Mitsuko. 2011. "Expectations and realities of education in post-conflict Sierra Leone: A reflection of society or a driver for peacebuilding?" In Education, Conflict and Development, ed. Julia Paulson, 119-144. Oxford: Symposium Books.

Mendenhall, Mary, and Nivedita Chopra. 2016. "Educating for peace in Kenya: Insights and lessons learned from peace education initiatives across the country." In Peace Education: International Perspectives, eds. Monisha Bajaj, and Maria Hantzopoulos, 89-106. London: Bloomsbury.

Ministerial Review Committee. 2004. Review of School Governance in South African Public Schools: Report of the Ministerial Review Committee on School Governance. Pretoria: Government Press.

Mncube, Vusi. 2005. "School governance in the democratisation of education in South Africa: The interplay between policy and practice." Unpublished $\mathrm{PhD}$ diss., University of Birmingham.

Mthiyane, S. 2013. "School governing bodies in addressing issues of violence in South African schools." Unpublished PhD diss., University of KwaZulu Natal.

Naidoo, R. 2012. "Experiences and practices of school principles in creating, leadiong and governing democratic school." Unpublished $\mathrm{PhD}$ diss., University of KwaZulu Natal.

Najjuma, R. 2011. "Peace education in the context of post-conflict formal schooling: The effectiveness of the revitalising education participation and learning in conflict affected areas peace education programme in Northern Uganda." Unpublished Ph.D diss., University of Birmingham.

Novelli, Mario, and Sean Higgins. 2017. "The violence of peace and the role of education: Insights from Sierra Leone." Compare: A Journal of Comparative and International Education 47 (1): 32-45.

Novelli, Mario, Sean Higgins, Mehmet Ugur, and Oscar Valiente. 2014. The Political Economy of Education Systems in Conflict-Affected Contexts. London: Department for International Development.

Novelli, Mario, and Alan Smith. 2011. The Role of Education in Peacebuilding: A Synthesis 
Report of Findings from Lebanon, Nepal and Sierra Leone. New York: UNICEF.

Pinheiro, Paulo Sérgio. 2006. World Report on Violence Against Children. Geneva: United Nations.

Quaynor, Laura J. 2011. "Citizenship education in post-conflict contexts: A review of the literature." Education, Citizenship and Social Justice 7 (1): 33-57.

Republic of South Africa. 1996. The Constitution. Pretoria: Government Printer.

Sharkey, Donna. 2008. "Contradictions in girls education in a post-conflict setting." Compare: A Journal of Comparative and International Education 38 (5): 569-579.

Shepler, S. 2011. "Helping our children will help in the reconstruction of our country: Repatriated refugee teachers in post-conflict Sierra Leone and Liberia." In Educating Children in Conflict Zones, eds. Karen Mundy, and Sarah Dryden-Peterson, 199-218. New York: Teachers College Press.

Smith, Alan. 2010. "The influence of education on conflict band peacebuilding." Background paper prepared for the Education For All global monitoring report 2011 - The Hidden Crisis: Armed Conflict and Education. https://www.gcedclearinghouse.org/sites/ default/files/resources/The\%20Influence\%20of\%20education\%20on\%20conflict\%20 and\%20peace\%20building.pdf (accessed April 23, 2018).

UNESCO (United Nations Educational, Scientific and Cultural Organization). 1945. "UNESCO Constitution.” http://www.unesco.org/new/en/unesco/about-us/who-weare/history/constitution/ (accessed April 25, 2018).

UNESCO (United Nations Educational, Scientific and Cultural Organization). 2011. The Hidden Crisis: Armed conflict and Education. EFA Global Monitoring Report. Paris: UNESCO.

UNESCO (United Nations Educational, Scientific and Cultural Organization). 2013/2014. Teaching and Learning: Achieving Quality For All. EFA Global Monitoring Report. Paris: UNESCO.

Williams, Peter. 2006. Achieving Education For All: Good Practice in Crisis and Post-Conflict Reconstruction. London: Commonwealth Secretariat.

Wright, Cream. 1997. "Reflections on Sierra Leone: A case study." In Final Report and Case Studies of the Workshop on Educational Destruction and Reconstruction in Disrupted Societies, ed. Sobhi Tawil, 17-30. Paris: UNESCO.

Zembylas, Michalinos. 2016. "Emotion, trauma and critical pedagogy: Implications for critical peace education." In Peace Education: International Perspectives, eds. Monisha Bajaj, and Maria Hantzopoulos. London: Bloomsbury.

Clive Harber is Emeritus Professor of International Education at the University of Birmingham. Between 1995 and 1995 he was Head of the School of Education at the then University of Natal, Durban (now KwaZulu Natal). He has a long standing interest in education for peace and democracy on the one hand and education for violence and authoritarianism on the other. He also has a particular interest in education and development and education in sub-Saharan Africa. He has published widely on these themes. Recent publications include Education, Democracy and Development (with V. Mncube - Symposium 2012), Education in Southern Africa (Edited - Bloomsbury 2013) and Education and International Development: Theory, Practice and Issues (Symposium 2014). Schools and Violence: South Africa in an International Context (with V. Mncube - UNISA Press) and Schooling in Sub-Saharan Africa: Policy, Practice and Patterns (Palgrave Macmillan) have both been published in 
2017. Email: C.R.Harber@bham.ac.uk

Submitted: January 16, 2018; Revised: January 23, 2018; Accepted: March 25, 2018 
